\title{
THE IMPACT OF MANAGERIAL STOCK OPTION ON FIRM RISK TAKING: EVIDENCE FROM CHINA
}

\author{
DOI: 10.17261/Pressacademia.2019.1041 \\ JBEF- V.8-ISS.2-2019(3)-p.101-113 \\ Ratny Seng ${ }^{1}$, Kimly Heng ${ }^{2}$, Gao-Liang Tian $^{3}$, Mohammad Arshad Arif ${ }^{4}$, Hua Feng ${ }^{5}$ \\ ${ }^{1} X^{\prime}$ 'an Jiaotong University, School of Management, Shaanxi, P. R. China \\ ratnys@yahoo.com, sengratny@gmail.com, ORCID: 0000-0002-6261-8223 \\ ${ }^{2} \mathrm{Xi}$ 'an Jiaotong University, School of Management and School of Energy, Shaanxi, P. R. China \\ kimly lucky@yahoo.com,ORCID: 0000-0001-8818-1659 \\ ${ }^{3}$ Xi'an Jiaotong University, School of Management, Shaanxi, P. R. China \\ tian.gl@mail.xjtu.edu.cn ORCID: 0000-0002-7336-4759 \\ ${ }^{4}$ Xi'an Jiaotong University, School of Management, Shaanxi, P. R. China \\ E-mail: marshadarif@yahoo.com \\ ${ }^{5}$ Xi' an Jiaotong University, School of Management, Shaanxi, P. R. China \\ emailfenghua@163.com, huafeng2-c@my.cityu.edu.hk_ORCID: 0000-0003-3141-2545
}

Date Received: April 25, 2019

Date Accepted: May 27, 2019

To cite this document

Seng, R., Heng, K., Tian, G., Arif, M., Feng, H. (2019). The impact of managerial stock option on firm risk taking: evidence from China. Journal of Business, Economics and Finance (JBEF), V.8(2), p.101-113,

Permemant link to this document: http://doi.org/10.17261/Pressacademia.2019...

Copyright: Published by PressAcademia and limited licenced re-use rights only.

\begin{abstract}
Purpose- This study is to investigate the firm risk-taking which influence by managerial of stock option.

Methodology- The empirical analysis of multiple regressions with a robustness test of OLS and STATA software were used in this study. In order to make our findings more practically and reliable, more robust tests have been applied, such as Fixed Effect Model with cluster standard error, Propensity Score Matching Model (PSM) and Dummy Effect Model.

Findings- stock option processing management has a significant positive impact on firm risk taking, market to book value, firm leverage, blockholder, asset turnover and portfolio have significant positive effects on firm risk taking. Firm size and state ownership have a significant negative impact on firm risk taking. Board does not influence on firm risk. It suggests top managers tend to use their power in managerial operation of stock option to manipulate earnings through employee stock option schemes, which causes companies to face high risk. Last result revealed that state ownership is helping to keep an eye on the corporation operation as a monitoring person.

Conclusion- Based on the results, this study delivered essential implication policy for investors, regulators, top manager as well as governance to take action in order to improve equity incentive system more effectively as well as to build healthier security markets in the world.

Keywords: managerial, stock option, firm risk, China

JEL Codes: G30, G32, M00

\section{INTRODUCTION}

Employee stock options is characterized as one of equity compensation that companies granted to their employees, key personnel, executives and top management. Companies provide the holder the legal right to purchase companies' shares at a listed price to get a constrained time frame with amounts that can be explained in the agreement. Companies use stock option as a type of retaining highly qualified employees with the purpose of boosting the corporations' stock price as well as whole operating performances. However, countless arguments and questions arose which involves stock option outcome. As an example, (Abowd \& Kaplan, 1999) questioned what is the consequences of employee stock option and how does it cost the firm. Alternatively, (Lambert, Larcker, \& Verrecchia, 1991) criticized that stock option compensation offer to CEOs could lead to decrease in corporate dividends, such as, huge increases in stock option lead to decrease in dividend out, (Jolls, 1998). On the other hand, stock option caused dividend rate to fall, (Fama et al., 2001). In addition, the stock option may cause and influence
\end{abstract}


management decisions-making, (DeFusco, Zorn, \& Johnson, 1991). Coinciding with the massive increase in the unique option, extensive academics literature seem to have emerged, one of them investigated by (Kevin J Murphy, 1999), process where management stock option and remuneration possessing affected the bureau relationship. Proof shows that the lower pay to performances association projected by (Jensen \& Murphy, 1990) has substantially been increased via stock option explosion due to managers holdings stock option as well as corporations' shares within their own portfolios, (Hall \& Liebman, 1998). Moreover, the relationship of result pay to performance is apparently in contract with agreement by using simple predictions concerning agent theory, (Aggarwal \& Samwick, 2002). Basically, it seems to be clear that the specific stock option explosion delivers greater certain alignment amongst managements and shareholder interests. Therefore, it is lowering the agency conflict, although not everyone is able to agree with this specific conclusion, (Yermack, 1995).

This research comprises of companies listed in Shen Zhen and Shanghai Stock Exchanges including both State and Non-State Enterprises in mainland China. To the best of our knowledge, we provide the 1st empirical evidence outlining the market's reaction to stock option implementation in China. China started to apply the stock options mechanism in the late 1990s, (L. Ross \& Zhou, 2005). It has matured its policy with time ${ }^{1}$, although implementing extensively in developed countries. Chinese capital market presents a unique situation in the study of the economic factors related to stock options as the institutional context in China is extremely distinctive from others; legal protection is weakened since many restrictions on incentives were imposed. In addition, China stock option has many extraordinary characteristics such as required to showing good performance and annual vesting, etc. Since stock option is the expense of the firms, in terms of providing remuneration. There is a concern which frequently is feasible on those options, and this may not only lead to harmful pay outs, but also the typically worth reward furnished by much larger upon the entire managing equity stakes. In particular, stock option enjoys an incredible asymmetric reimbursement and usually do not pay any dividends.

Bryan et al (2000) suggest that stock options can be used to reduce, rather than induce, firms' risk-taking behavior because executives' personal portfolios become less diversified when stock-based compensation increases. It was considered that the real value of option goes up with organization's volatility, which tends to give benefits to top management which may raise firm's risk-taking. However, the direction of causation between employees' stock options and firm risk-taking (FRT) is not usually discussed in the literature. Thus, our study is aimed to fulfill this gap.

In this particular study, we evaluated the effect on organization risk taking of managerial stock option in China, which has been increasing since 2005; once the regulator-mandated shares reform, converting the sizable amount of earlier non-tradable share help by controlling shareholders into fully tradable shares. This study empirically assesses: 1) the relationship between the stock options granted to all employees and its increase in FRT. Concern with biases caused by self-selections, we used OLS models with robustness as the main identification strategy and with other robustness tests such as fixed effects and propensity score methods as well as Dependent variables' dummy's mean value. 2) How corporate governance and ownership structures affect the stock option incentives and FRT? The existing theories about the impact of worker's stock option and the unique characteristics of China, such as the corporate governance's body and companies' ownership structure were used to verify their impacts on FRT.

Our research contributes to the literatures around employee's stock option that granted effect on FRT in numerous approaches: firstly, to our awareness, it is the $1^{\text {st }}$ research that dispatches the FRT influence by stock option management in various types of companies utilizing up-to-date huge sample in China. Secondly, while many of the existing research concentrate on American companies, we examine the issue in an emerging market like China. Aside from the discovering that stock option incentive effect FRT, we also revealed that ownership structures, especially state-owned enterprises (SOEs) are crucial towards the accomplishment of stock option granted. The remainder of the paper is prepared as below. Section 2 provides the literature review and hypotheses. Section 3 describes the design. While, Section 4 presents the results and discussion. Finally, Section 5 offers the conclusion.

\footnotetext{
${ }^{1}$ In 2002, Ministry of Finance and Ministry of Science and Technology jointly promulgated several regulations with respect to the granting of stock option in state-owned high-tech companies. In January 2006, China Securities Regulatory Commission (CSRC) promulgated the measure for the administration of equity incentive of listed companies (trial). The measures, for the first time, systematically provide detailed guidelines for the implementation of stock option and stock-based incentive schemes for employees in listed companies.
} 


\section{RELATED LITERATURE AND HYPOTHESIS DEVELOPMENT}

The effectiveness of stock option can broadly be characterized, (DeFusco et al., 1991; Easterbrook, 1984; Lewellen, Loderer, \& Martin, 1987). They found that dividends tend to decrease for firm, while executive stock options were expected to increase. Thus, a managerial stock option plan selected by a manager may influence on the dividend policy. In addition, there exists an assumption that there is a cause and effect connection between stock option compensation and superior managerial decision making as proven in the study of (DeFusco et al., 1991). Their findings provide evidence that with the decrease in firm experiences, earning and cumulative abnormal return leads to increase in stock option incentive plan. It suggests that the related studies suffer from the dynamic endogeneity problem since poor performance may lead to subsequent changes in board composition. Moreover, when firms proposing changes in managerial stock option experience, there is a statistically significant decline in expenditure on research and development. Besides, selling and administrative costs were found to be increased. There is a belief that in order to get more advantages for themselves, managers decided to award stock option in potential period. This was found by (Yermack, 1997) who explains that stock option award time has a clear relationship with contemporaneous activities in firm share prices, while stock return is increased slightly in the trading day after following time of CEO option award and the new option award is not disclosed for several months even in a fiscal year end. He also observed that CEOs obtain stock option award before the opening of beneficial corporate news.

Risk is considered to be one of the main factors in managerial decision and strategic management research, (Ruefli, Collins, \& Lacugna, 1999). Previous studies suggest that risk behavior measurement concentrates on the dispositional characteristics of people in charge of decision making ${ }^{2}$, (Hambrick, Cho, \& Chen, 1996) and the organizational and industrial contexts affecting managerial risk-taking behavior, (Bromiley, 1991; Palmer \& Wiseman, 1999). For non-bank organizations such as stated ownership structure as endogenous, while firm-risk is viewed as exogenous, (Demsetz \& Lehn, 1985). From researchers' perspective, the riskier environment and the larger incentives are for shareholders. Thus, they could change the managerial structure of the firm in order to convert it into shareholder-owned firms. As discussed by (Saunders, Strock, \& Travlos, 1990), through the increment on directors' stock ownership in the company, their riskiness incentives develop into closer alignment to those of shareholders only if their ownership share is not as much as their assets proportion. Otherwise, it could bring more concern to shareholders over nonsystematic risk (risk aversion) of firms' performance. Evidence found that executives' stock boosts value to shareholders, which encourage them to deal with firms' risk, the increment in option hold by executives statistically increased risk taking, Cohen and Hall (2000). Therefore, we hypothesize the prediction as follows:

$\mathbf{H}_{1}$ : Stock option (in-term of a number of shares) which companies granted to all employees has a positive significant correlation with FRT.

Stock option normally needs to estimate its value. ${ }^{3}$ Therefore, we propose our second hypothesis as follows:

$\mathbf{H}_{2}$ : Stock option (in-term of the market monitor) which companies granted to all employees is positively correlated with FRT.

In accordance with market-value theory, market circumstances determine and form the particular settlements of CEOs (Kevin J. Murphy \& Zábojník, 2004). Once managers obtained option incentives it means they are same as stockholders, thus they will pursue strategies that increase firms' risk. Consequently, in order to maximize their option value the company will face additional risk. Thus, we predict that stock option base compensation ${ }^{4}$ should have a positive impact on firms' risk and we propose our third hypothesis as follow:

$\mathbf{H}_{3}$ : Stock option based compensation (in term of monitoring value of cost $^{5}$ or stock option revenue, (Huddart \& Lang, 1996)) is positive and significantly associated with FRT.

\footnotetext{
${ }^{2}$ Mostly, managers are afraid to take riskiness decision since the backward incentives are limited. They are particularly focus on the employment and operational risk rather than shareholders' profit, (Baysinger \& Hoskisson, 1990).

${ }^{3}$ Chinese firms are required to recognize the fair value of employee stock options according to China's accounting standard.

${ }^{4}$ Value of firm's risk and managers' risk aversion are the main determination of ownership shares impact on risk-taking. Stock options compensation can reduce total firm risk (Carpenter, 2000; Lambert et al., 1991; S. A. Ross, 2004).

${ }^{5}$ Compensation cost, including the estimated value of employee stock options, is properly included in measuring net income (Huddart \& Lang, 1996).
} 


\section{RESEARCH DESIGN}

\subsection{SAMPLE DESCRIPTION}

To test the above hypotheses, the data samples are acquired manually through stock option grant notices of every individual company. Data was collected from China Stock Market Accounting Research (CSMAR) and both websites of Shenzhen and Shanghai Stock Exchange. While, State control ownership data were obtained from Wind Database. CSMAR is the source of risktaking determination and other financial data.

Following previous works, in order to get more effective results, we omitted missing data and excluded financial and banking sector firms from the sample. To ensure that the results are not motivated by means of outliers, dependent variable and some control variables data was winsorized at $1 \%$ ( 1 and 99 percentiles). The final unbalance sample is 221 firms and 482 (SOE=98 \& Non-SOE=384) financial firm-year observations, which consist of eight years consecutively during the period of 2006 and 2013.

\subsection{DETERMINANTS CONSTRUCTION}

\subsubsection{FIRM RISK-TAKING VARIABLES}

In order to examine the particular FRT propensities of our tested managerial stock options, we employed accounting as well as market risk measures as an attempt to enhance the robustness regarding our study which follows (Wright, Kroll, Krug, \& Pettus, 2007). According to their study, particularly, we used the lagged standard deviation of the firms' annual returns on assets (ROA), likewise the lagged standard deviation of regular annual total returns to shareholders (RTS).

\subsubsection{MANAGERIAL STOCK OPTION INDICATORS}

For managerial stock option measurement, we defined several variables such as options granted percentage (SOP), it is the measurement of stock option size, which is calculated by dividing between total number of options granted and total outstanding shares then multiply by 100, (Luo, 2015a; Triki \& Ureche-Rangau, 2012) and one other variable is a stock option market value (SOM). A typical option in China will certainly vest within three equivalent installments; one-third upon every single subsequent three anniversaries regarding to the date of granted. Since, stock option is non-dividend option policy payment in China, thus we use Black-Scholes (1973) model to estimate the value of stock option. Total value of stock option is calculated by multiplying between Black-Scholes single value and total number of share of option granted (FischerBlack \& MyronScholes, 1973).

Furthermore, we follow (Luo, 2015b; Triki \& Ureche-Rangau, 2012) to calculate SOM by taking the total option value divided by the market value of equity. Last variable is the logarithm of stock option base compensation (SOC), stock option base compensation is to measure the volumes of stock option revenue, which is calculated by total stock option grant multiplied by stock price then multiplied by $1 \%$ (Li \& Sanseau, 2013). As stock options have several opponent benefits upon managing added benefits. The initial one inseminating from the level of sensitivity connected with option to share gain volatility. Since, stock options have convex payoff structure; as a consequence, the value of stock option increase along with the movement of stock returns.

\subsubsection{CONTROL VARIABLES}

According to the previous studies on similar area, the wide range of predictors which was used to determine the effect of managerial stock option on FRT is introduced. Such control variables have been identified by prior studies, including firm size, independent director ratio, market book value, leverage, block-holders' shares, Herfindahl index, asset turnover, year and industry type dummy.

The extra awards and remunerations could influence the degree of company risk taking. For control variables, firm size (SIZE) is measured by the logarithm of a total number of each firm's employees. It is indicated that FRT might have a significant influence on company size, (Wright et al., 2007). In addition, the proportion of independent director (IDR) is calculated by the number of independent board member divided by the total number of board members, and the higher proportion of independent as board members, the further scrutiny in term of managerial action on behalf of investors occurs, (Wright et al., 2007).

Moreover, we included the proportion of block-holders' shares and outstanding shares (BLH) as another indicator. Since blockholders are those who owe five percent or more of outstanding shares, and have a tendency to press managers with regard to innovative management, (Wright et al., 2007). We also include a market-to-book value (MTV), it is the market value of assets over book values of assets as a proxy for the opportunity of growth, (Coles, Daniel, \& Naveen, 2006; Rajgopal \& Shevlin, 2002). 
Additionally, firm leverage (LEV) is simply determined by the ratio of total interest bearing debts to equity. We made the calculation in order to control related actual impact of the existing liabilities amount on potential risk, (Faccio, Marchica, \& Mura, 2011). Follow by their study; Herfindahl Index ${ }^{6}$ is a measurement of wealth concentration for the portfolio owned by each firm's largest shareholder $\left(H H I=\sum_{j}^{J}=\omega_{i j}^{2}\right.$ ). The index ranges from 0 to 1 , that 0 demonstrates a total diversified portfolio and 1 indicates the total assets that is invested in one firm.

Where $\mathrm{HHI}^{7}$ is calculated by summing the squared values percentage market shares held by respective firms (Faccio et al., 2011). From the review of various literatures, we adopt one of the operating costs to be our control variable; asset turnover (ATO). The measurement of asset turnover is the ratio of sales to assets. Where ATO ${ }^{8}$ represents total asset turnover, sales represent net sales and assets equal total assets in a specific period (Singh, Davidson III, \& Suchard, 2003). In addition, we include a state own enterprise (SOE) dummy variable to control between private and state owned firms, number 1 was assigned to the companies that are state owned and 0 are on the contrary. Finally, we also use YEAR and industry dummy variables (IND) to capture variations across industries and time period (Chourou, Abaoub, \& Saadi, 2008).

\subsection{EMPIRICAL MODELS}

The empirical equation models for estimating the influence of managerial stock option on organizational risk are described as follows:

Equation 1 is used for multiple regressions with robustness to test whether firms with SOPs present greater ROAs.

$R O A=\alpha+\sum_{i=1}^{n} \beta_{1} F C+\beta_{2} S O P+\varepsilon$

Equation 2 is used for multiple regressions with robustness to test whether firms with SOMs present greater ROAs.

$$
R O A=\alpha+\sum_{i=1}^{n} \beta_{1} F C+\beta_{2} S O M+\varepsilon
$$

Equation 3 is used for multiple regressions with robustness to test whether firms with SOCs present greater ROAs.

$$
R O A=\alpha+\sum_{i=1}^{n} \beta_{1} F C+\beta_{2} S O C+\varepsilon
$$

Equation 4 is used for multiple regressions with robustness to test whether firms with SOPs present greater RTSs.

$$
R T S=\alpha+\sum_{i=1}^{n} \beta_{1} F C+\beta_{2} S O P+\varepsilon
$$

Equation 5 is used for multiple regressions with robustness to test whether firms with SOMs present greater RTSs.

$$
R T S=\alpha+\sum_{i=1}^{n} \beta_{1} F C+\beta_{2} S O M+\varepsilon
$$

Equation 6 is used for multiple regressions with robustness to test whether firms with SOCs present greater RTSs.

$$
R T S=\alpha+\sum_{i=1}^{n} \beta_{1} F C+\beta_{2} S O C+\varepsilon
$$

Where FRT indicates firm risk, $\alpha$ is the intercept of each model, ROA is a dependent variable which demonstrates lagged standard deviation of the firms' annual returns on assets, RTS is a dependent variable which represents lagged standard deviation of regular annual total returns to shareholders. In addition, SOP is an independent variable which determines stock option size, SOM is an independent variable which represents the stock option market value, and SOC is an independent variable

${ }^{6}$ Ownership structure in the organization tends to be in greater attention when Herfindahl index indicates greater values (Lacouture et al., 2008).

${ }^{7}$ In the study of (Faccio et al., 2011), HHI was used as an independent variable. As regressions results interpret that the higher value of the index denotes the more portfolios diversified.

${ }^{8}$ It is important to note that total asset turnover is the only inverse proxy variable for agency costs, meaning that agency costs increase as total asset turnover decreases. 
which represents the stock option base compensation. While FC is control variable, $n$ is the numbers of control variables, $i$ stands for the specific control variable where $i=1 \sim n$.

\section{RESULTS AND DISCUSSION}

\subsection{DESCRIPTIVE STATISTICS}

The descriptive statistics of stock option, ownership characteristics and control variables are demonstrated in Table 1 . The table delivers insightful information about the 25 th percentile, $50^{\text {th }}$ percentile, 75 th percentile, mean and standard deviation of important indicators. During 4 operation years, mean of ROA of 221 listed firms is 0.03 , the standard deviation is 0.04 , while mean of RTS is 0.48 and the standard deviation is 0.51 . These numbers indicate that those firms have incompatible operating risk characteristics. For independent variables in this study, mean of SOP is 2.59 and its standard deviation is 1.88 . In addition, mean of SOM is 0.88 and its standard deviation is 1.19 , while mean of SOC is 5.92 and its standard deviation is 0.53 .

Table 1. Descriptive Statistics

\begin{tabular}{|c|c|c|c|c|c|c|c|}
\hline Variable & Mean & SD & P25 & P50 & P75 & Min & Max \\
\hline ROA & 0.03 & 0.04 & 0.01 & 0.02 & 0.04 & 0.00 & 0.38 \\
\hline RTS & 0.48 & 0.51 & 0.08 & 0.33 & 0.77 & -0.10 & 2.71 \\
\hline SOP & 2.59 & 1.88 & 1.31 & 2.14 & 3.35 & 0.18 & 10.00 \\
\hline SOM & 0.88 & 1.19 & 0.22 & 0.50 & 1.03 & 0.01 & 9.63 \\
\hline SOC & 5.92 & 0.53 & 5.56 & 5.94 & 6.26 & 3.94 & 7.38 \\
\hline IDR & 0.38 & 0.05 & 0.33 & 0.36 & 0.43 & 0.25 & 0.67 \\
\hline MBV & 1.01 & 1.00 & 0.36 & 0.62 & 1.34 & 0.07 & 7.93 \\
\hline LEV & 0.44 & 0.24 & 0.25 & 0.43 & 0.59 & 0.00 & 1.25 \\
\hline BLH & 8.26 & 0.55 & 7.88 & 8.22 & 8.60 & 6.92 & 9.95 \\
\hline SIZE & 3.37 & 0.54 & 3.00 & 3.33 & 3.70 & 2.10 & 4.87 \\
\hline ATO & 0.78 & 0.56 & 0.40 & 0.65 & 0.96 & 0.00 & 4.15 \\
\hline $\mathrm{HHI}$ & 0.02 & 0.05 & 0.38 & 0.57 & 0.85 & 0.00 & 3.37 \\
\hline
\end{tabular}

Note: This table illustrates the summary statistics of dependent, independent and control determinants

\subsection{COEFFICIENT CORRELATION}

Appendix 1 demonstrates the correlation between proposed variables. By using correlation analysis, the results indicate the interaction between dependent, independent and control variables. The results of ROA and RTS (dependent variables) were strongly positive significant correlation with SOM, SOP and SOC (independent variables). It means that stock options in term of a number of shares, market value and compensation increases in respect to FRT. Besides, it happens that there exist no significant relationship between dependent variables and the three control variables which are: IDR, SIZE and SOE. Moreover, most independent and control variables are statistically associated except LEV, SIZE, ATO and SOE. 


\subsection{REGRESSION ANALYSIS}

Table 2. Regression analysis of managerial stock options with FRT

\begin{tabular}{|c|c|c|c|c|c|c|}
\hline & \multicolumn{3}{|c|}{ ROA } & \multicolumn{3}{|c|}{ RTS } \\
\hline & Model 1 & Model 2 & Model 3 & Model 4 & Model 5 & Model 6 \\
\hline \multirow[t]{2}{*}{ SOP } & $0.00498^{* * *}$ & & & $0.0767^{* *}$ & & \\
\hline & (5.48) & & & $(6.33)$ & & \\
\hline \multirow[t]{2}{*}{ SOM } & & $0.00852^{* * *}$ & & & $0.126^{* * *}$ & \\
\hline & & (5.54) & & & (6.15) & \\
\hline \multirow[t]{2}{*}{ SOC } & & & $0.0183^{* * *}$ & & & $0.207^{* * *}$ \\
\hline & & & $(5.27)$ & & & (4.39) \\
\hline \multirow[t]{2}{*}{ IDR } & $0.0611^{* *}$ & $0.0556^{*}$ & $0.0506^{*}$ & $0.689^{*}$ & 0.594 & 0.465 \\
\hline & (2.03) & (1.86) & (1.69) & (1.71) & (1.48) & (1.14) \\
\hline \multirow[t]{2}{*}{ MBV } & $0.0133^{* * *}$ & $0.0138^{* * *}$ & $0.0149^{* * *}$ & $0.0865^{* *}$ & $0.0955^{* * *}$ & $0.118^{* * *}$ \\
\hline & $(6.47)$ & (6.79) & (7.47) & (3.15) & $(3.51)$ & $(4.34)$ \\
\hline \multirow[t]{2}{*}{ LEV } & $0.0187^{* *}$ & $0.0289^{* * *}$ & $0.0273^{* * *}$ & $0.175^{*}$ & $0.330^{* * *}$ & $0.303^{* * *}$ \\
\hline & (2.40) & (3.76) & (3.55) & (1.68) & $(3.21)$ & (2.89) \\
\hline \multirow[t]{2}{*}{ BLH } & $0.0138^{* * *}$ & $0.0106^{* * *}$ & $0.00901^{* * *}$ & $0.157^{* * *}$ & $0.108^{* *}$ & $0.0891^{* *}$ \\
\hline & $(4.31)$ & $(3.38)$ & $(2.85)$ & (3.68) & $(2.57)$ & $(2.07)$ \\
\hline \multirow[t]{2}{*}{ SIZE } & $-0.0232^{* * *}$ & $-0.0233^{* * *}$ & $-0.0305^{* * *}$ & $-0.181^{* * *}$ & $-0.183^{* * *}$ & $-0.276^{* * *}$ \\
\hline & $(-6.51)$ & $(-6.54)$ & $(-8.43)$ & $(-3.79)$ & $(-3.85)$ & $(-5.60)$ \\
\hline \multirow[t]{2}{*}{ ATO } & $0.00816^{* *}$ & $0.00659^{*}$ & $0.00969^{* * *}$ & $0.155^{* * *}$ & $0.132^{* * *}$ & $0.177^{* * *}$ \\
\hline & $(2.38)$ & $(1.90)$ & (2.82) & $(3.38)$ & $(2.85)$ & $(3.80)$ \\
\hline \multirow[t]{2}{*}{$\mathrm{HHI}$} & $0.152^{* *}$ & $0.141^{* * *}$ & $0.107^{*}$ & $2.55^{* * *}$ & $2.419^{* * *}$ & $2.238^{* * *}$ \\
\hline & (2.82) & $(2.61)$ & $(1.92)$ & $(3.56)$ & $(3.35)$ & $(2.94)$ \\
\hline \multirow[t]{2}{*}{ SOE } & $-0.00725^{*}$ & $-0.0106^{* * *}$ & $-0.00909^{* *}$ & $-0.0517^{* *}$ & $-0.104^{* *}$ & $-0.0918^{*}$ \\
\hline & $(-1.83)$ & $(-2.74)$ & $(-2.33)$ & $(-1.98)$ & $(-2.01)$ & $(-1.73)$ \\
\hline Year & YES & YES & YES & YES & YES & YES \\
\hline IND & YES & YES & YES & YES & YES & YES \\
\hline \multirow[t]{2}{*}{ Constant } & $-0.0763^{* *}$ & $-0.0483^{*}$ & $-0.106^{* * *}$ & $-0.729^{*}$ & -0.285 & $-0.869^{*}$ \\
\hline & $(-2.51)$ & $(-1.65)$ & $(-3.24)$ & $(-1.80)$ & $(-0.73)$ & $(-1.95)$ \\
\hline $\mathrm{N}$ & 482 & 482 & 482 & 482 & 482 & 482 \\
\hline Adj. $R^{2}$ & 0.313 & 0.314 & 0.31 & 0.318 & 0.314 & 0.286 \\
\hline $\mathrm{F}$ & 8.586 & 8.624 & 8.466 & 8.744 & 8.626 & 7.651 \\
\hline
\end{tabular}

Notes: ROA is a dependent variable which is the measurement of firms' annual returns on assets; moreover, RTS is a dependent variable which is the determination of regular annual total returns to shareholders. T statistic in parentheses when $* p<0.05,{ }^{* *} p<0.01, * * * p<0.001$

Table 2 illustrates logistic regressive estimation of the impact of stock option on FRT. By further investigation of the correlations, it does not show any multicollinearity issue ${ }^{9}$ with the tested variables (Akinwande, Dikko, \& Samson, 2015), but shows a mean

\footnotetext{
${ }^{9}$ Studies reveal that Variance Inflation Factor (VIF) exceeding 5 is not good for regression model because it might render other significant variables redundant, while VIFs exceeding 10 are signs of serious multicollinearity in need of correction.
} 
variance inflation element (VIF) of 1.4 and a maximum VIF of 1.466. This study uses multiple regressions with a robustness test to investigate whether stock option management influence firms' risk by using equation (1) up to (6). As clearly demonstrated in Table 2, Model from 1 to 6 tested the interaction between firms' risk and options in terms of share, market monitor and cost. The coefficients of the interaction terms are positive and strongly significant, $(p>.001)$ proves those assigned hypotheses are supported. Both market munificence and complexity strengthen the relationship between options and FRT. Result suggests that all stock option variables are positively influenced by all dependent variables such as ROA, RTS which is identical to the pattern of stock option assigned purpose. In addition, the estimated coefficient on IDR shows no correlation with FRT, firms do not consider risk regardless of the number of board members. Result generates that LEV is positive and significant consistence, suggesting that highly levered firms appear to take on higher risk. The estimated coefficient on MBV, ATO and BLH are positively significant correlated with ROA and RTS. It claims that firms with larger market value and turnover tend to undertake greater exploration risk. Conversely, the coefficient on SIZE generates a negative significant relationship. This result suggested that risk taking incentives decrease when a number of employees increase. However, SOE shows a negative relationship with a coefficient. This result recommended that state ownership possesses greater power to manage firms' operation and restrict shareholders from manipulation which leads to reducing firms' risk. Thus, we can observe evidently that the influence of SOE on FRT is weakened. Moreover, state ownership is helping to monitor the expenses, such as stock option size, market value and revenue ${ }^{10}$.

\subsection{ROBUSTNESS TEST}

Table 3. Effects of stock option on FRT (Regression of Fixed Effect Model with cluster standard error)

\begin{tabular}{|c|c|c|c|c|c|c|}
\hline & \multicolumn{3}{|c|}{ ROA } & \multicolumn{3}{|c|}{ RTS } \\
\hline & Model 1 & Model 2 & Model 3 & Model 4 & Model 5 & Model 6 \\
\hline SOP & $\begin{array}{c}0.00903^{* * *} \\
(2.78)\end{array}$ & & & $\begin{array}{c}0.0682^{* *} \\
(2.30)\end{array}$ & & \\
\hline SOM & & $\begin{array}{c}0.00581^{*} \\
(1.65)\end{array}$ & & & $\begin{array}{c}0.111^{* * *} \\
(2.68)\end{array}$ & \\
\hline SOC & & & $\begin{array}{r}0.0124^{*} \\
(1.66)\end{array}$ & & & $\begin{array}{c}0.276^{* * *} \\
(3.54)\end{array}$ \\
\hline IDR & $\begin{array}{l}0.180^{*} \\
(1.88)\end{array}$ & $\begin{array}{l}0.177^{*} \\
(1.82)\end{array}$ & $\begin{array}{l}0.170^{*} \\
(1.76)\end{array}$ & $\begin{array}{l}0.704 \\
(0.81)\end{array}$ & $\begin{array}{l}0.770 \\
(0.88)\end{array}$ & $\begin{array}{l}0.644 \\
(0.75)\end{array}$ \\
\hline MBV & $\begin{array}{c}0.0118^{* * *} \\
(2.71)\end{array}$ & $\begin{array}{c}0.0120^{* * *} \\
(2.71)\end{array}$ & $\begin{array}{c}0.0126^{* * *} \\
(2.85)\end{array}$ & $\begin{array}{c}0.0494 \\
(1.24)\end{array}$ & $\begin{array}{c}0.0435 \\
(1.09)\end{array}$ & $\begin{array}{l}0.0541 \\
(1.38)\end{array}$ \\
\hline LEV & $\begin{array}{c}0.00450 \\
(0.25)\end{array}$ & $\begin{array}{c}0.00982 \\
(0.54)\end{array}$ & $\begin{array}{c}0.00738 \\
(0.41)\end{array}$ & $\begin{array}{c}0.364^{* *} \\
(2.22)\end{array}$ & $\begin{array}{c}0.440^{* * *} \\
(2.68)\end{array}$ & $\begin{array}{c}0.395^{* *} \\
(2.45)\end{array}$ \\
\hline BLH & $\begin{array}{c}0.0194^{* *} \\
(2.57)\end{array}$ & $\begin{array}{r}0.0149^{*} \\
(1.97)\end{array}$ & $\begin{array}{c}0.0183^{* *} \\
(2.37)\end{array}$ & $\begin{array}{c}0.249^{* * *} \\
(3.62)\end{array}$ & $\begin{array}{c}0.204^{* * *} \\
(3.00)\end{array}$ & $\begin{array}{c}0.276^{* * *} \\
(4.03)\end{array}$ \\
\hline SIZE & $\begin{array}{c}0.0379 \\
(1.25)\end{array}$ & $\begin{array}{c}0.0333 \\
(1.08)\end{array}$ & $\begin{array}{c}0.0255 \\
(0.84)\end{array}$ & $\begin{array}{l}-0.271 \\
(-0.98)\end{array}$ & $\begin{array}{l}-0.212 \\
(-0.77)\end{array}$ & $\begin{array}{l}-0.360 \\
(-1.34)\end{array}$ \\
\hline ATO & $\begin{array}{c}0.00989 \\
(0.89)\end{array}$ & $\begin{array}{c}0.0106 \\
(0.94)\end{array}$ & $\begin{array}{c}0.0101 \\
(0.89)\end{array}$ & $\begin{array}{c}0.228^{* *} \\
(2.24)\end{array}$ & $\begin{array}{c}0.226^{* *} \\
(2.22)\end{array}$ & $\begin{array}{c}0.211^{* *} \\
(2.10)\end{array}$ \\
\hline $\mathrm{HHI}$ & $\begin{array}{l}0.272 \\
(1.06)\end{array}$ & $\begin{array}{l}0.373 \\
(1.45)\end{array}$ & $\begin{array}{l}0.341 \\
(1.32)\end{array}$ & $\begin{array}{c}9.475^{* * *} \\
(4.04)\end{array}$ & $\begin{array}{c}10.07^{* * *} \\
(4.36)\end{array}$ & $\begin{array}{c}9.312^{* * *} \\
(4.05)\end{array}$ \\
\hline Cons. & $\begin{array}{c}-0.309^{* *} \\
(-2.53)\end{array}$ & $\begin{array}{c}-0.240^{* *} \\
(-1.99)\end{array}$ & $\begin{array}{c}-0.307^{* *} \\
(-2.25)\end{array}$ & $\begin{array}{l}-1.227 \\
(-1.10)\end{array}$ & $\begin{array}{l}-1.042 \\
(-0.96)\end{array}$ & $\begin{array}{c}-2.609^{* *} \\
(-2.16)\end{array}$ \\
\hline$N$ & 482 & 482 & 482 & 482 & 482 & 482 \\
\hline Within $R^{2}$ & 0.2307 & 0.2102 & 0.2116 & 0.4144 & 0.4191 & 0.4321 \\
\hline$F$ & 5.72 & 5.08 & 5.12 & 13.51 & 13.77 & 14.52 \\
\hline
\end{tabular}

Notes: ROA is a dependent variable which is the measurement of firms' annual returns on assets; moreover, RTS is a dependent variable which is the determination of regular annual total returns to shareholders. T statistic in parentheses when $* p<0.05, * * p<0.01, * * * p<0.001$

\footnotetext{
${ }^{10}$ It is found that politically connected board chairs have greater excess compensation for non-state owned firms, but not for state owned firms.
} 
In order to provide more supportive findings of this paper, we intend to repeatedly test the variables by using robustness test. In this section, we present the important robustness check of the results obtained from ordinary least squares (OLS) regression regarding the estimation of stock option influence on firm's risk taking by using three robustness analyses as: (a) Fixed Effect Model with cluster standard error instead of OLS model (We exclude SOE variable from this analysis), (b) Propensity Score matching Model (PSM) to find the most similar group of stock option, then we used match sample to run the regression again as resulting from a concern of possible endogeneity problem, and (c) the calculation of mean values of SOP_dummy, SOM_dummy and SOC_dummy in same industry and year as concerning the extreme values effect, if the original values are larger than the mean values, then we take value as 1 , and 0 otherwise.

Table 3 delivers analytical results of regressions of stock option and FRT by Fixed Effect Model. It illustrates that all stock option variables generate as follows: SOP has positive significant with ROA $(p<.01)$, while SOM and SOC present no significant correlation with ROA ( $p>$.05). In addition, from Table 3, RTS exists to have a significant connection with SOP, SOM and SOC with a coefficient of $(p<.01),(p<.001)$ and $(P<.001)$ respectively.

Table 4 indicates results of stock option on FRT under Propensity Score matching Model regression. Results showed that SOP and SOC are positively connected with ROA ( $p<.01)$, while SOM shows insignificant influence. Besides, there exists a strong positive significant relationship between SOP, SOM and SOC with RTS $(P<.001)$.

Table 4. Effects of stock option on FRT (Propensity Score matching Model Regression)

\begin{tabular}{|c|c|c|c|c|c|c|}
\hline & & ROA & & & RTS & \\
\hline SOP & $\begin{array}{c}\text { Model } 1 \\
0.00523^{* *} \\
(2.59)\end{array}$ & Model 2 & Model 3 & $\begin{array}{c}\text { Model } 4 \\
0.0785^{* * *} \\
(4.98)\end{array}$ & Model 5 & Model 6 \\
\hline SOM & & $\begin{array}{c}0.00243^{*} \\
(1.65)\end{array}$ & & & $\begin{array}{c}0.133^{* * *} \\
(3.82)\end{array}$ & \\
\hline SOC & & & $\begin{array}{c}0.0210^{* *} \\
(2.45)\end{array}$ & & & $\begin{array}{c}0.271^{* * *} \\
(4.37)\end{array}$ \\
\hline IDR & $\begin{array}{l}0.122 \\
(1.31)\end{array}$ & $\begin{array}{l}0.128 \\
(1.33)\end{array}$ & $\begin{array}{c}0.123^{*} \\
(1.65)\end{array}$ & $\begin{array}{c}1.422^{* *} \\
(2.45)\end{array}$ & $\begin{array}{c}1.257^{* *} \\
(2.12)\end{array}$ & $\begin{array}{c}0.392 \\
(0.78)\end{array}$ \\
\hline MBV & $\begin{array}{c}0.00471 \\
(0.82)\end{array}$ & $\begin{array}{c}0.0106 \\
(1.56)\end{array}$ & $\begin{array}{c}0.00779 \\
(1.31)\end{array}$ & $\begin{array}{c}0.0723^{* *} \\
(2.06)\end{array}$ & $\begin{array}{c}0.101^{* * *} \\
(3.07)\end{array}$ & $\begin{array}{c}0.108 * * * \\
(3.37)\end{array}$ \\
\hline LEV & $\begin{array}{c}-0.000853 \\
(-0.05)\end{array}$ & $\begin{array}{c}0.0321 \\
(1.54)\end{array}$ & $\begin{array}{c}0.000853 \\
(0.05)\end{array}$ & $\begin{array}{c}0.272^{* *} \\
(1.99)\end{array}$ & $\begin{array}{c}0.483^{* * *} \\
(3.70)\end{array}$ & $\begin{array}{c}0.432 * * * \\
(3.51)\end{array}$ \\
\hline BLH & $\begin{array}{c}0.0317^{* * *} \\
(3.04)\end{array}$ & $\begin{array}{c}0.0154 \\
(1.56)\end{array}$ & $\begin{array}{c}0.0311^{* * *} \\
(4.16)\end{array}$ & $\begin{array}{c}0.213^{* * *} \\
(3.23)\end{array}$ & $\begin{array}{c}0.0170 \\
(0.31)\end{array}$ & $\begin{array}{c}0.0645 \\
(1.23)\end{array}$ \\
\hline SIZE & $\begin{array}{c}-0.0262^{* * *} \\
(-2.91)\end{array}$ & $\begin{array}{c}-0.0325^{* * *} \\
(-3.14)\end{array}$ & $\begin{array}{c}-0.0452^{* * *} \\
(-4.71)\end{array}$ & $\begin{array}{l}-0.146^{* *} \\
(-2.23)\end{array}$ & $\begin{array}{c}-0.0305 \\
(-0.45)\end{array}$ & $\begin{array}{c}-0.354 * * * \\
(-5.42)\end{array}$ \\
\hline ATO & $\begin{array}{c}0.00517 \\
(0.69)\end{array}$ & $\begin{array}{c}0.0137 \\
(1.56)\end{array}$ & $\begin{array}{c}0.0128 * \\
(1.86)\end{array}$ & $\begin{array}{c}0.156^{* *} \\
(2.34)\end{array}$ & $\begin{array}{c}0.0773 \\
(1.26)\end{array}$ & $\begin{array}{c}0.183^{* * *} \\
(3.20)\end{array}$ \\
\hline $\mathrm{HHI}$ & $\begin{array}{l}0.262 \\
(1.38)\end{array}$ & $\begin{array}{c}0.0561 \\
(0.46)\end{array}$ & $\begin{array}{l}0.203 \\
(1.27)\end{array}$ & $\begin{array}{c}4.010^{* * *} \\
(2.76)\end{array}$ & $\begin{array}{c}2.422^{* * *} \\
(2.67)\end{array}$ & $\begin{array}{c}3.662^{* *} \\
(2.44)\end{array}$ \\
\hline SOE & $\begin{array}{c}-0.0133^{*} \\
(-1.65)\end{array}$ & $\begin{array}{c}-0.0215 \\
(-1.64)\end{array}$ & $\begin{array}{c}-0.00519^{*} \\
(-0.65)\end{array}$ & $\begin{array}{r}-0.0338^{*} \\
(-1.67)\end{array}$ & $\begin{array}{c}-0.261^{* * *} \\
(-3.62)\end{array}$ & $\begin{array}{c}-0.158 * * \\
(-2.52)\end{array}$ \\
\hline Cons. & $\begin{array}{c}-0.209^{* * *} \\
(-3.06)\end{array}$ & $\begin{array}{c}0.0145 \\
(0.20)\end{array}$ & $\begin{array}{c}-0.229 * * * \\
(-3.14)\end{array}$ & $\begin{array}{c}-1.483^{* *} \\
(-2.40)\end{array}$ & $\begin{array}{c}-0.0121 \\
(-0.02)\end{array}$ & $\begin{array}{c}-0.846^{*} \\
(-1.73)\end{array}$ \\
\hline$N$ & 260 & 226 & 327 & 260 & 226 & 327 \\
\hline$R^{2}$ & 0.3398 & 0.2418 & 0.2647 & 0.4205 & 0.4153 & 0.3439 \\
\hline
\end{tabular}


Notes: ROA is a dependent variable which is the measurement of firms' annual returns on assets; moreover, RTS is a dependent variable which is the determination of regular annual total returns to shareholders. T statistic in parentheses when $* p<0.05,{ }^{* *} p<0.01, * * * p<0.001$

Table 5 indicates results of stock option on FRT by using regression dummy model. From the test, it is suggested that SOP is strongly associated with ROA $(\mathrm{P}<.001)$, SOC has a slight relationship with ROA $(p<.05)$, while SOM has no significant result.

The results indicate that RTS coefficient is positively significant in each model which is maintaining the same main results without any changes, while ROA coefficient is still positive significantly, but the level is weaker compared to the main results.

Table 5. Effects of stock option on FRT (Regression of Dummy Model)

\begin{tabular}{|c|c|c|c|c|c|c|}
\hline & & ROA_dumm & & & RTS_dummy & \\
\hline SOP & $\begin{array}{c}\text { Model 1 } \\
0.0183^{* * *} \\
(3.19)\end{array}$ & Model 2 & Model 3 & $\begin{array}{c}\text { Model } 4 \\
0.252^{* * *} \\
(5.18)\end{array}$ & Model 5 & Model 6 \\
\hline SOM & & $\begin{array}{c}0.00598^{*} \\
(1.86)\end{array}$ & & & $\begin{array}{c}0.260^{* * *} \\
(5.43)\end{array}$ & \\
\hline SOC & & & $\begin{array}{c}0.0111^{*} \\
(1.65)\end{array}$ & & & $\begin{array}{c}0.181^{* * *} \\
(4.04)\end{array}$ \\
\hline IDR & $\begin{array}{l}0.0645 \\
(1.04)\end{array}$ & $\begin{array}{c}0.0405 \\
(0.65)\end{array}$ & $\begin{array}{c}0.0534 \\
(0.86)\end{array}$ & $\begin{array}{l}0.613 \\
(1.53)\end{array}$ & $\begin{array}{l}0.259 \\
(0.66)\end{array}$ & $\begin{array}{l}0.488 \\
(1.19)\end{array}$ \\
\hline MBV & $\begin{array}{c}0.00634 \\
(1.24)\end{array}$ & $\begin{array}{c}0.00852 \\
(1.55)\end{array}$ & $\begin{array}{c}0.00864 \\
(1.61)\end{array}$ & $\begin{array}{c}0.0925^{* * *} \\
(3.60)\end{array}$ & $\begin{array}{c}0.0910^{* * *} \\
(3.65)\end{array}$ & $\begin{array}{c}0.122^{* * *} \\
(4.78)\end{array}$ \\
\hline LEV & $\begin{array}{c}-0.000264 \\
(-0.02)\end{array}$ & $\begin{array}{c}0.00831 \\
(0.58)\end{array}$ & $\begin{array}{c}0.00832 \\
(0.57)\end{array}$ & $\begin{array}{l}0.173 \\
(1.55)\end{array}$ & $\begin{array}{c}0.293^{* * *} \\
(2.68)\end{array}$ & $\begin{array}{c}0.292^{* * *} \\
(2.64)\end{array}$ \\
\hline BLH & $\begin{array}{c}0.0370^{* * *} \\
(5.15)\end{array}$ & $\begin{array}{c}0.0344^{* * *} \\
(4.77)\end{array}$ & $\begin{array}{c}0.0333^{* * *} \\
(4.67)\end{array}$ & $\begin{array}{c}0.145^{* * *} \\
(3.43)\end{array}$ & $\begin{array}{c}0.119^{* * *} \\
(2.90)\end{array}$ & $\begin{array}{c}0.0917^{* *} \\
(2.18)\end{array}$ \\
\hline SIZE & $\begin{array}{c}-0.0338^{* * *} \\
(-4.61)\end{array}$ & $\begin{array}{c}-0.0366^{* * *} \\
(-4.84)\end{array}$ & $\begin{array}{c}-0.0395^{* * *} \\
(-5.37)\end{array}$ & $\begin{array}{c}-0.175^{* * *} \\
(-3.68)\end{array}$ & $\begin{array}{c}-0.181^{* * *} \\
(-3.88)\end{array}$ & $\begin{array}{c}-0.258^{* * *} \\
(-5.20)\end{array}$ \\
\hline ATO & $\begin{array}{c}0.0133^{* *} \\
(2.32)\end{array}$ & $\begin{array}{c}0.0131^{* *} \\
(2.24)\end{array}$ & $\begin{array}{c}0.0133^{* *} \\
(2.27)\end{array}$ & $\begin{array}{c}0.166^{* * *} \\
(3.32)\end{array}$ & $\begin{array}{c}0.136^{* *} \\
(2.57)\end{array}$ & $\begin{array}{c}0.163^{* * *} \\
(3.04)\end{array}$ \\
\hline $\mathrm{HHI}$ & $\begin{array}{l}0.140^{*} \\
(1.80)\end{array}$ & $\begin{array}{c}0.185^{* *} \\
(2.35)\end{array}$ & $\begin{array}{c}0.176^{* *} \\
(2.36)\end{array}$ & $\begin{array}{c}2.365^{* * *} \\
(3.38)\end{array}$ & $\begin{array}{c}2.343^{* * *} \\
(3.34)\end{array}$ & $\begin{array}{c}2.788^{* * *} \\
(3.89)\end{array}$ \\
\hline SOE & $\begin{array}{c}-0.00503^{*} \\
(-1.69)\end{array}$ & $\begin{array}{c}-0.00873 \\
(-1.03)\end{array}$ & $\begin{array}{c}-0.00824^{*} \\
(-1.96)\end{array}$ & $\begin{array}{c}-0.0606^{*} \\
(-1.69)\end{array}$ & $\begin{array}{c}-0.0836^{*} \\
(-1.65)\end{array}$ & $\begin{array}{c}-0.101^{* *} \\
(-1.97)\end{array}$ \\
\hline Year & Control & Control & Control & Control & Control & Control \\
\hline IND & Control & Control & Control & Control & Control & Control \\
\hline Cons. & $\begin{array}{c}-0.213^{* * *} \\
(-4.06)\end{array}$ & $\begin{array}{c}-0.179^{* * *} \\
(-3.44)\end{array}$ & $\begin{array}{c}-0.168^{* * *} \\
(-3.30)\end{array}$ & $\begin{array}{l}-0.498 \\
(-1.24)\end{array}$ & $\begin{array}{l}-0.169 \\
(-0.44)\end{array}$ & $\begin{array}{l}0.145 \\
(0.35)\end{array}$ \\
\hline$N$ & 482 & 482 & 482 & 482 & 482 & 482 \\
\hline$R^{2}$ & 0.2825 & 0.2704 & 0.2748 & 0.3431 & 0.3455 & 0.3248 \\
\hline
\end{tabular}

Notes: We calculated the mean values of ROA_dummy and RTS_dummy in same industry and year, if the original values are larger than the mean values, then we take the value as 1 , and 0 otherwise. T statistic in parentheses: $* p<0.05, * * p<0.01, * * * p<0.001$.

The above results establish the concrete evidence for supporting our findings, which illustrates the significant influence of stock option on FRT as demonstrated in Table 3, 4 and 5. 


\section{CONCLUSION}

The motivation of our study is potentially determined by the lag of theoretical and empirical evidence upon the link between managerial incentives and FRT with research framework especially on a regulated market. As a transitional economy with relationship-based financial system in China, stock option influences and government involvement have a significant influence on FRT behavior. It shows that under Chinese-specific institution as well as surrounding regulation, stock options are likely to have a positive influence on FRT. Thus, stock option can be considered as a determining factor for top managers to use stock option managerial as profit earning mechanism. This finding shed light on the link of stock option to the companies and implemented it.

This research statistically examines significant and robust connection between option-based compensation and risk taking on proposed equations. The findings of the study show that firms dramatically increase their usage of option-based compensation followed by the increment in FRT. A higher proportion of incentives is likely to be positively associated with subsequent FRT. Apparently, in growth concentrated FRT, the firm value may increase, enhancing the worth of managerial incentives. The larger proportion of share, monitoring value and market monitor implements riskier policy choices, it could lead to riskier assets investment. This result supported various empirical studies, which generally found a positive relationship between stock options and different measurement of FRT, (DeFusco, Johnson, \& Zorn, 1990; Guay, 1999; Schrand \& Unal, 1998).

We anticipate that these findings contain important implications for both scholars and practitioners. From the viewpoints of researchers interested in stock option managerial, the results of this study should provide insightful information on how stock options have impacts on FRT behavior in particular.

\section{ACKNOWLEDGEMENTS}

Gaoliang Tian wishes to acknowledge and recognizes the financial support from National Natural Science Foundation of China (Project No. 71372163 and 71672141)

\section{REFERENCES}

Abowd, J. M., \& Kaplan, D. S. (1999). Executive Compensation: Six Questions That Need Answering. Journal of Economic Perspectives, 13(4), 145168.

Aggarwal, R., \& Samwick, A. (2002). The other side of the tradeoff: The impact of risk on executive compensation-A reply.

Akinwande, M. O., Dikko, H. G., \& Samson, A. (2015). Variance inflation factor: As a condition for the inclusion of suppressor variable (s) in regression analysis. Open Journal of Statistics, 5(07), 754.

Baysinger, B., \& Hoskisson, R. E. (1990). The composition of boards of directors and strategic control: Effects on corporate strategy. Academy of Management review, 15(1), 72-87.

Bromiley, P. (1991). Testing a causal model of corporate risk taking and performance. Academy of Management journal, 34(1), 37-59.

Carpenter, J. N. (2000). Does option compensation increase managerial risk appetite? The Journal of Finance, 55(5), $2311-2331$.

Chourou, L., Abaoub, E., \& Saadi, S. (2008). The economic determinants of CEO stock option compensation. Journal of Multinational Financial Management, 18(1), 61-77. doi: https://doi.org/10.1016/j.mulfin.2007.05.001

Coles, J. L., Daniel, N. D., \& Naveen, L. (2006). Managerial incentives and risk-taking. Journal of Financial Economics, 79(2), $431-468$.

Defusco, R. A., Johnson, R. R., \& Zorn, T. S. (1990). The effect of executive stock option plans on stockholders and bondholders. The Journal of Finance, 45(2), 617-627.

DeFusco, R. A., Zorn, T. S., \& Johnson, R. R. (1991). The association between executive stock option plan changes and managerial decision making. Financial Management, 36-43.

Demsetz, H., \& Lehn, K. (1985). The structure of corporate ownership: Causes and consequences. Journal of political economy, 93(6), $1155-1177$.

Easterbrook, F. H. (1984). Two agency-cost explanations of dividends. The American Economic Review, 74(4), 650-659.

Faccio, M., Marchica, M.-T., \& Mura, R. (2011). Large shareholder diversification and corporate risk-taking. The Review of Financial Studies, 24(11), 3601-3641.

Fama, E., French, K., Fenn, G. W., Liang, N., Busaba, W. Y., Benveniste, L. M., . . . Mian, S. (2001). 1. Disappearing dividends: changing firm characteristics or lower propensity to pay? Journal of Financial Economics, 60(1), 1-176. 
FischerBlack, \& MyronScholes. (1973). The pricing of options and corporate liabilities. Journal of political economy, 81(3), 637-654.

Guay, W. R. (1999). The sensitivity of CEO wealth to equity risk: an analysis of the magnitude and determinants. Journal of Financial Economics, 53(1), 43-71.

Hall, B. J., \& Liebman, J. B. (1998). Are CEOs Really Paid Like Bureaucrats?*. The Quarterly Journal of Economics, 113(3), 653-691. doi: $10.1162 / 003355398555702$

Hambrick, D. C., Cho, T. S., \& Chen, M.-J. (1996). The influence of top management team heterogeneity on firms' competitive moves. Administrative science quarterly, 659-684.

Huddart, S., \& Lang, M. (1996). Employee stock option exercises an empirical analysis. Journal of Accounting and Economics, 21(1), 5-43.

Jensen, M. C., \& Murphy, K. J. (1990). Performance pay and top-management incentives. Journal of political economy, 98(2), 225-264.

Jolls, C. (1998). Stock repurchases and incentive compensation: National bureau of economic research.

Lacouture, M. E., Wu, S., Robert, C., Atkins, M. B., Kong, H. H., Guitart, J., . . Alexandrescu, D. T. (2008). Evolving strategies for the management of hand-foot skin reaction associated with the multitargeted kinase inhibitors sorafenib and sunitinib. The oncologist, 13(9), $1001-1011$.

Lambert, R. A., Larcker, D. F., \& Verrecchia, R. E. (1991). Portfolio considerations in valuing executive compensation. Journal of Accounting Research, 129-149.

Lewellen, W., Loderer, C., \& Martin, K. (1987). Executive compensation and executive incentive problems: An empirical analysis. Journal of Accounting and Economics, 9(3), 287-310.

Li, L., \& Sanseau, P.-Y. (2013). Influential Factors Of Executives' Equity-Based Revenue In Chinese- Listed Companies. Jounal of Applied Business Research, 29(2), 379.

Luo, L. (2015a). Determinants Of Stock Option Use By Chinese Companies. The Journal of Applied Business Research, 31(4), $1355-1376$.

Luo, L. (2015b). Determinants Of Stock Option Use By Chinese Companies. Journal of Applied Business Research, 31(4), 1355.

Murphy, K. J. (1999). Executive compensation. Handbook of labor economics, 3, 2485-2563.

Murphy, K. J., \& Zábojník, J. (2004). CEO Pay and Appointments: A Market-Based Explanation for Recent Trends. American Economic Review, 94(2), 192-196. doi: doi: 10.1257/0002828041302262

Palmer, T. B., \& Wiseman, R. M. (1999). Decoupling risk taking from income stream uncertainty: A holistic model of risk. Strategic Management Journal, 20(11), 1037-1062.

Rajgopal, S., \& Shevlin, T. (2002). Empirical evidence on the relation between stock option compensation and risk taking. Journal of Accounting and Economics, 33(2), 145-171.

Ross, L., \& Zhou, K. (2005). Trading and distribution in China The international journal of cometition policy and regulation.

Ross, S. A. (2004). Compensation, incentives, and the duality of risk aversion and riskiness. The Journal of Finance, 59(1), 207-225.

Ruefli, T. W., Collins, J. M., \& Lacugna, J. R. (1999). Risk measures in strategic management research: auld lang syne? Strategic Management Journal, 20(2), 167-194.

Saunders, A., Strock, E., \& Travlos, N. G. (1990). Ownership structure, deregulation, and bank risk taking. The Journal of Finance, 45(2), 643-654.

Schrand, C., \& Unal, H. (1998). Hedging and coordinated risk management: Evidence from thrift conversions. The Journal of Finance, 53(3), 9791013.

Singh, M., Davidson III, W. N., \& Suchard, J.-A. (2003). Corporate diversification strategies and capital structure. The Quarterly Review of Economics and Finance, 43(1), 147-167.

Triki, T., \& Ureche-Rangau, L. (2012). Stock Options and Firm Performance: New Evidence from the French Market. Journal of International Financial Management \& Accounting, 23(2), 154-185. doi: 10.1111/j.1467-646X.2012.01057.x

Wright, P., Kroll, M., Krug, J. A., \& Pettus, M. (2007). Influences of top management team incentives on firm risk taking. Strategic Management Journal, 28(1), 81-89.

Yermack, D. (1995). Do corporations award CEO stock options effectively? Journal of Financial Economics, 39(2), 237-269. doi: https://doi.org/10.1016/0304-405X(95)00829-4

Yermack, D. (1997). Good timing: CEO stock option awards and company news announcements. The Journal of Finance, 52(2), 449-476. 


\section{Appendix 1. Correlation analysis}

\begin{tabular}{|c|c|c|c|c|c|c|c|c|c|c|c|c|c|}
\hline & ROA & RTS & SOP & SOM & $\mathrm{SOC}$ & IDR & MBV & LEV & BLH & SIZE & ATO & $\mathrm{HHI}$ & SOE \\
\hline ROA & 1.000 & & & & & & & & & & & & \\
\hline RTS & $0.412^{* * *}$ & 1.000 & & & & & & & & & & & \\
\hline SOP & $0.386^{* * *}$ & $0.389^{* * *}$ & 1.000 & & & & & & & & & & \\
\hline SOM & $0.362^{* * *}$ & $0.362^{* * *}$ & $0.492^{* * *}$ & 1.000 & & & & & & & & & \\
\hline SOC & $0.270^{* * *}$ & $0.309^{* * *}$ & $0.434^{* * *}$ & $0.318^{* * *}$ & 1.000 & & & & & & & & \\
\hline IDR & 0.064 & 0.032 & $-0.134^{* * *}$ & $-0.126^{* * *}$ & $-0.095^{* * *}$ & 1.000 & & & & & & & \\
\hline MBV & $0.186^{* * *}$ & $0.142^{* * *}$ & $0.166^{* * *}$ & $0.158^{* * *}$ & $0.267^{* * *}$ & -0.043 & 1.000 & & & & & & \\
\hline LEV & $0.197^{* * *}$ & $0.230^{* * *}$ & $0.126^{* * *}$ & 0.045 & $0.203^{* * *}$ & -0.041 & $0.338^{* * *}$ & 1.000 & & & & & \\
\hline BLH & $0.113^{* *}$ & $0.134^{* * *}$ & $-0.158^{* * *}$ & -0.019 & $0.225^{* * *}$ & 0.035 & $0.184^{* * *}$ & $0.394^{* * *}$ & 1.000 & & & & \\
\hline SIZE & -0.073 & -0.011 & -0.066 & -0.001 & $0.349^{* * *}$ & -0.068 & $0.341^{* * *}$ & $0.341^{* * *}$ & $0.352^{* * *}$ & 1.000 & & & \\
\hline ATO & $0.120^{* *}$ & $0.150^{* * *}$ & 0.070 & $0.158^{* * *}$ & $0.109^{* *}$ & -0.056 & 0.003 & $0.241^{* * *}$ & $0.166^{* * *}$ & $0.362^{* * *}$ & 1.000 & & \\
\hline $\mathrm{HHI}$ & $0.116^{* *}$ & $0.151^{* * *}$ & $0.085^{*}$ & $0.113^{* *}$ & $0.225^{* * *}$ & -0.020 & -0.041 & $0.174^{* * *}$ & 0.053 & $0.226^{* * *}$ & $0.248^{* * *}$ & 1.000 & \\
\hline SOE & $-0.105^{* *}$ & -0.056 & $-0.161^{* * *}$ & -0.032 & -0.039 & $-0.090^{*}$ & $0.156^{* * *}$ & $0.173^{* * *}$ & 0.056 & $0.232^{* * *}$ & $0.118^{*}$ & $0.146^{* * *}$ & 1.000 \\
\hline
\end{tabular}

Variable is significant at level $\mathrm{p}<0.05=*, \mathrm{p}<0.01=* *, \mathrm{p}<0.001=* * *$ respectively

Note: This table presents the correlation coefficients of the variables without raising any multicollinearity problem as its 'coefficients do not exceed 0.5 thus; variance influence factor also verified that there's no severe issue regarding multicollinearity. To ensure that the results are not motivated by means of outliers, we winsorized all dependent variable and some control variables at $1 \%$ ( 1 and 99 percentiles). White's examination intended for heteroscedasticity pointed out any heteroscedasticity issue. To be able to appropriate for heteroscedasticity, we use robust regression to repeatedly test the determinants. 